\begin{tabular}{|c|c|c|}
\hline Beitr. Ent. & Keltern & ISSN 0005-805X \\
\hline $\mathbf{5 3}(2003) 1$ & S. $161-165$ & 31.07 .2003 \\
\hline
\end{tabular}

\title{
Chromosomes of Aphidius ervi HALIDAY, 1834
}

\section{(Hymenoptera: Braconidae)}

With 5 figures and 2 tables

\section{VLADIMIR E. GOKHMAN and MAGDALENE WESTENDORFF}

\section{Summary}

Chromosome numbers of $\mathrm{n}=5$ and $2 \mathrm{n}=10$ were found in a few laboratory strains of Aphidius ervi HALIDAY, 1834 from Germany. However, several females having $2 n=12$ were detected in one of the populations studied. These females are likely to represent a thelytokous strain originating from an initially arrhenotokous one. The karyotype with $2 \mathrm{n}=12$ has a characteristic additional pair of fully heterochromatic acrocentric chromosomes.

\section{Zusammenfassung}

Die Chromosomenanalyse einiger Laborlinien von Aphidius ervi HALIDAY, 1834 aus Deutschland ergab $\mathrm{n}=5$ und $2 \mathrm{n}=10$. Allerdings wurden bei einigen weiblichen Tieren einer Population Chromosomensätze mit $2 \mathrm{n}=12$ gefunden. Diese Tiere repräsentieren wahrscheinlich eine thelytoke Linie, die aus einer ursprünglich arrhenotoken Population hervorging. Der Karyotyp mit $2 \mathrm{n}=12$ enthält ein zusätzliches charakteristisches Paar vollständig heterochromatischer akrozentrischer Chromosomen.

\section{Резгоме}

В нескольких лабораторных линиях наездника Aphidius ervi HALdDAY, 1834 из Германии обнаружено $\mathrm{n}=5$ и $2 \mathrm{n}=10$, однако в оАной из популяций найдены самки, имеющие $2 \mathrm{n}=12$. Эти самки, очевиАно, СоставАяют теАитокическую Аинию, возникшую внутрих исходной арренотокической попуАяции. Кариотип с $2 \mathrm{n}=12$ содержит характерную дополнительную пару полностью гетерохроматиновых акроцентрических хромосом.

\section{Keywords}

Chromosomes, Aphidius ervi, Hymenoptera: Braconidae

\section{Introduction}

Chromosomes of about twenty species of the braconid subfamily Aphidinae including a few members of the genus Apbidius NEES, 1819 have been studied up to now (GOKHMAN \& QUICKE, 1995; QUICKE \& BELSHAW, 1999; GOKHMAN, 2000). For Apbidius ervi 
HALIDAY, 1834 a haploid number $n=5$ has been found (QUICKE \& BELSHAW, 1999). However, our analysis of laboratory strains of $A$. ervi from Germany revealed several chromosome numbers including $2 \mathrm{n}=12$ (GOKHMAN, 2002). Results of this study are given below.

\section{Material and methods}

Laboratory cultures of $A$. ervi used were maintained in 1998-2001 at the University of Bayreuth, Germany, on Acyrtosiphon pisum HARRIS, 1776 (Homoptera, Aphididae) and originated from insects collected in natursil populations at Seybothenreuth $(10 \mathrm{~km}$ E Bayreuth). Air-dried chromosome preparations were made from prepupae of parasitic wasps according to the routine procedure described by IMAI et al. (1988). Differential chromosome staining (C-banding) was performed using the method developed by SUMNER (1972) and modified by GOKHMAN (1997). For chromosome measurements diploid metaphase plates were scanned directly from the preparations using an optic microscope fitted with a TV camera connected to a personal computer equipped with the image analysis program ImageExpert, version 1.0 . Scanned images were measured using Adobe Photoshop, retsion 4.3.

Abbreviations used: M- metacentric, SM- submetacentric, A- acrocentric, NFn- haploid arm number, NFdiploid atm number.

\section{Results}

Among the studied individuals of $A$. ervi, $n=5(4 M+1 S M) ; N F n=10$ and $2 n=10(8 M+$ $2 \mathrm{SM}$ ); $\mathrm{NF}=20$ have been found in most males and females respectively (Tab. 1 ). These karyotypes include three comparatively large metacentrics followed by a smaller submetacentric and another metacentric chromosome (Tab. 2, Figs 1, 2). However, three females examined in 1998 showed $2 n=12(8 M+2 S M+2 A) ; N F=22(T a b .1)$. In addition to the chromosomes characteristic of most individuals with $2 n=10$, females with $2 n=12$ appeared to have a pair of small acrocentrics (Tab. 2, Fig. 3). Nevertheless, a thorough study of available adult specimens from different strains revealed no morphological differences between them. C-banding demonstrated that most chromosomes contained only small heterochromatic segments, except for the pair of acrocentrics in the karyotype with $2 \mathrm{n}=12$. These chromosomes were fully heterochromatic and usually occupied a peripheral position within the dividing nucleus (Figs 4, 5).

Tab. 1: Numbers of studied individuals of Aphidius ervi

\begin{tabular}{|c|c|c|c|}
\hline Year & \multirow{2}{*}{1998} & \multirow{2}{*}{2000} & \multirow{2}{*}{2001} \\
\hline Chr Number & & & \\
\hline$n=5$ & 5 & 3 & 1 \\
\hline $2 n=10$ & 6 & 2 & 1 \\
\hline $2 n=6$ & 3 & - & - \\
\hline
\end{tabular}


Tab. 2: Chromosomal parameters of diploid karyotypes of Aphidius eri: Relative length (RL), (RL* - last pair of chromosomes excluded) and centromeric index (CI)

\begin{tabular}{|c|c|c|c|c|c|}
\hline \multirow{2}{*}{ Chr no. } & \multicolumn{2}{|c|}{ form with $2 \mathrm{n}=10$} & \multicolumn{3}{|c|}{ form with $2 n=12$} \\
\hline & RI. & $\mathrm{Cl}$ & $\mathrm{RL} *$ & $\mathrm{RL}$ & $\mathrm{Cl}$ \\
\hline 1 & $24.08 \pm 0.52$ & $45.04 \pm 2.27$ & $23.78 \pm 0.67$ & $21.52 \pm 0.65$ & $46.32 \pm 2.65$ \\
\hline 2 & $21.79 \pm 0.81$ & $47.61 \pm 2.12$ & $22.21 \pm 0.52$ & $20.11 \pm 0.49$ & $47.11 \pm 2.66$ \\
\hline 3 & $21.60 \pm 0.79$ & $41.68 \pm 2.56$ & $21.28 \pm 1.26$ & $19.26 \pm 1.15$ & $42.14 \pm 5.00$ \\
\hline 4 & $17.31 \pm 1.15$ & $30.71 \pm 3.04$ & $17.10 \pm 0.82$ & $15.48 \pm 0.77$ & $29.41 \pm 4.53$ \\
\hline 5 & $15.22 \pm 0.98$ & $46.79 \pm 1.82$ & $15.63 \pm 0.39$ & $14.15 \pm 0.35$ & $45.01 \pm 3.27$ \\
\hline 6 & - & - & - & $9.48 \pm 0.72$ & $0.00 \pm 0.00$ \\
\hline
\end{tabular}

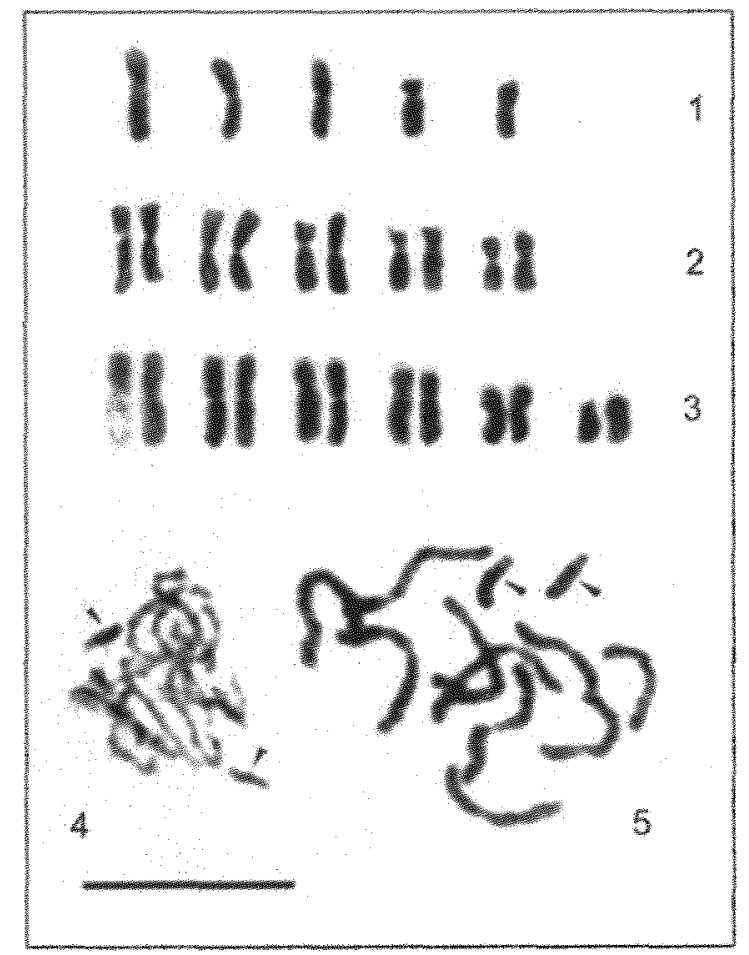

Figs 1-5. Chromosomes of Apbidius ervi. 1 - form with $2 n=10$, haploid karyogram; 2 - ditto, diploid karyogram; 3 - form with $2 \mathrm{n}=12$, diploid karyogram; 4 - ditto, $C$-banded prophase; 5 - ditto, prometaphase. Acrocentrics on Figs 4 and 5 are indicated with arrowheads. Scale bar equals $10 \mu \mathrm{m}$. 


\section{Discussion}

Judging from an increased variation of certain structural characteristics (Tab. 2), diploid karyotypes of $A$. ervi apparently bear some rearrangements (see GOKHMAN, 1998). Nevertheless, the morphometric analysis indicates that these chromosome sets are virtually identical except for the last pair of acrocentric chromosomes in individuals with $2 n=12$. Some features of these elements (e.g. comparatively small size, positive heteropycnosis and specific behaviour during mitosis) are similar to those characteristic of many B chromosomes found in insects and other animals (WHITE, 1973; WERREN et al., 1988). However, acrocentrics from the karyotype with $2 n=12$ differ from $B$ chromosomes by the absence of detected numerical variation within individuals. Moreover, neither females with $2 n=11$ nor males with $n=6$ have been found.

Since too few studied specimens showed deviant chromosome numbers $(2 n=12)$, the possibility of contamination of the initial culture with a foreign species cannot be fully excluded. However, karyotypes of the Aphidiinae are very diverse in terms of their chromosome numbers and morphology. Specifically, $\mathrm{n}=3,5,6$, and 7 has been found in several members of the genus Aphidius (GOKHMAN, 2000). It seems extremely unlikely that two separate species which develop on the same host could have very similar chromosome sets. Therefore it is more probable that the wasps having $2 \mathrm{n}=12$ represent a separate thelytokous strain originating from the initial arrhenotokous one with $n=5$ and $2 n=10$. This view is further supported by the fact that the origin of ,asexual" ( $=$ thelytokous) forms has been observed in various members of the Aphidiinae including in the genus Apbidius (BELSHAW et al., 1999). If this explanation is true, C-positive acrocentrics in $A$. ervi could bear a specific factor which causes thelytoky in insects with $2 n=12$.

\section{Acknowledgements}

We are very grateful to W. VÖLKL and U. SCHWÖRER (University of Bayreuth, Germany) for providing living samples of laboratory stocks of Apbidius ervi and Acyrtosiphon pisum as well as for important information regarding these cultures. The authors also appreciate assistance provided by $\mathrm{A}$. TAEGER (Deutsches Entomologisches Institut, Eberswalde) who checked the identity of adult specimens from the studied strains. We thank A. D. LISTON (Frontenhausen), who kindly corrected the English. The present study was partly supported by a grant from the Deutscher Akademischer Austauschdienst (Bonn) to V. E. GOKHMAN.

\section{References}

BELSHAW, R.; QUICKE, D. L. J.; VÖLKL, W. \& GODFRAY, H. C. J. 1999: Molecular markers indicate rare sex in a predominantly asexual parasitoid wasp. - Evolution $\mathbf{5 3}$ (4): 1189-1199.

GOKHMAN, V. E. 1997: Differential chromosome staining in parasitic wasps of the genus Dirophanes (Hymenoptera, Ichneumonidae). - Entomological Review 77 (2): 263-266 (original Russian version was published in: Zoologichesky Zhurnal 76 (1): 65-68.

GOKHACAN, V. E. 1998: Karyotype evolution and sex determination in parasitic wasps (Hymenoptera). - In: BRUNHOFER, V. \& SOLDAN T. (eds.): The VIth European Congress of Entomology. Česke Budejovice, Czech Republic, August 23-29, 1998. Book of Abstracts (Proceedings of the VIth European Congress of Entomology). Sections 1 to 5: 163-164. 
GOKHMAN, V. E. 2000: Karyology of parasitic Hymenoptera: current state and perspectives. - In: AUSTIN, A. D. \&. DowToN M. (eds.): Hymenoptera: Evolution, Biodiversity and Biological Control. Collingwood, CSIRO Publishing: 198-206.

GOKHMAN, V. E. 2002: Chromosomal analysis of the superfamilies Ichneumonoidea and Chalcidoidea (Hymenoptera). - In: MELIKA, G. \& THUROCzY C. (eds). Parasitic wasps: evolution, systematics, biodiversity and biological control. Budapest, Agroinform: 243-248.

GOKHIMAN, V. E. \& QUICKE, D. L. J. 1995: The last twenty years of parasitic Hymenoptera karyology: an update and phylogenetic implications. - Journal of Hymenoptera Research 4: 41-63.

IMAI, H. T.; TAYLOR, R. W.; CROSLAND, M. W. J. \& CROZIER R. H. 1988: Modes of spontaneous chromosomal mutation and karyotype evolution in ants with reference to the minimum interaction hypothesis. - Japanese Journal of Genetics 63: 159-185.

QUICKE, D. L. J. \& BELSHAW, R. 1999: Incongruence between morphological data sets: an example of endoparasitism among parasitic wasps (Hymenoptera: Braconidae). - Systematic Biology 48 (3): 436-454.

SUMNER, A. T. 1972: A simple technique for demonstrating centromeric heterochromatin. - Experimental Cell Research 75: 304-306.

WERREN, J. H.; NUR, U. \& WU, CH.-I. 1988: Selfish genetic elements. - Trends in Ecology and Evolution 3 (11): 297-302.

WhitE, M. J. D. 1973: Animal cytology and evolution. - Cambridge: Cambridge University Press. 961 pp.

\section{Authors' addresses:}

VLADIMIR E. GOKHMAN

Botanical Garden

Moscow State University

119899 Moscow

Russia

e-mail: sadmgu@online.ru
Dr. MAgDalene WestendorfF

Deutsches Entomologisches Institut

im Zentrum für Agrarlandschafts- und

Landnutzungsforschung (ZALF)

Schicklerstraße 5

D-16225 Eberswalde, Germany

e-mail:westendorff@zalf.de 